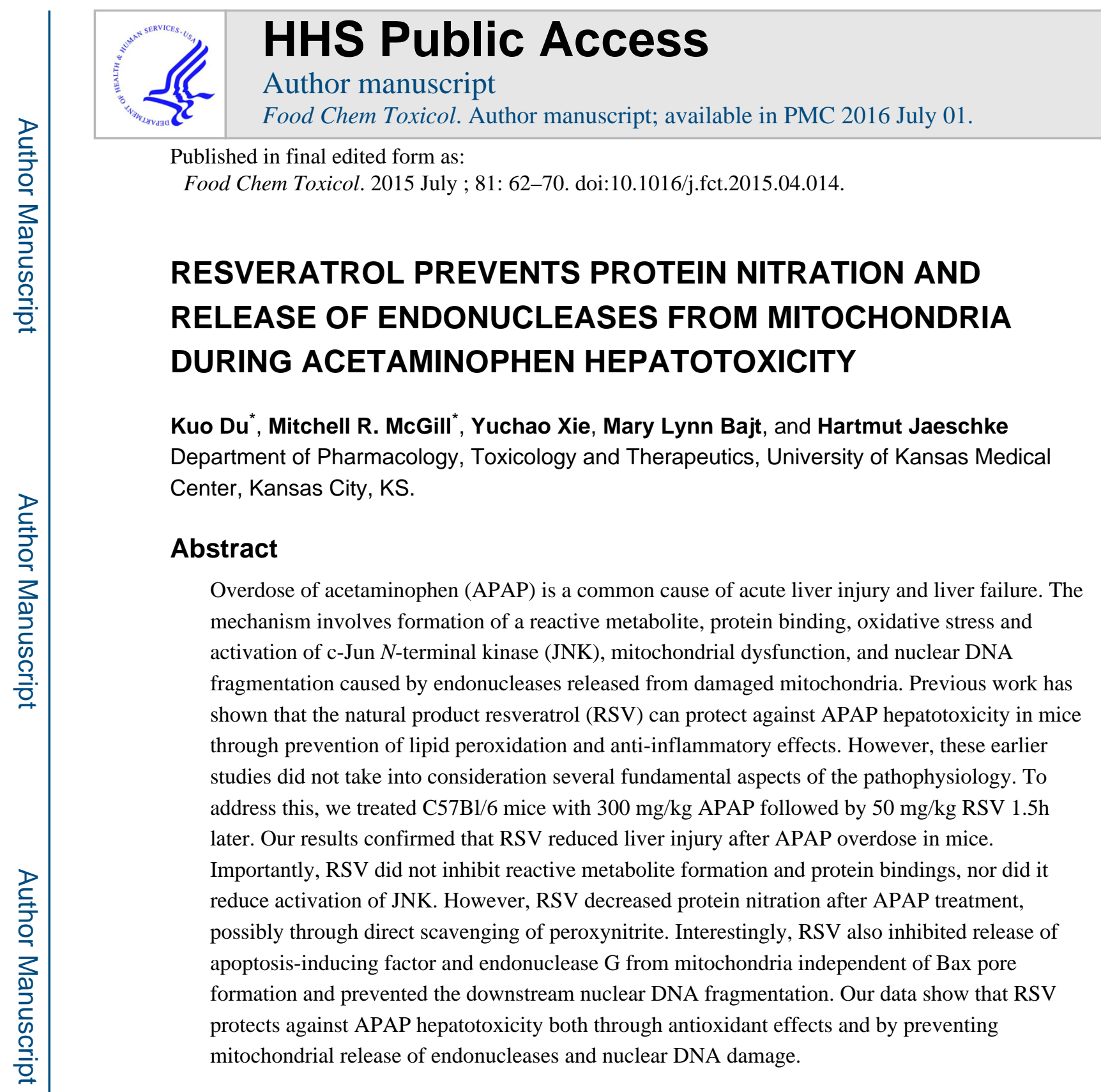

\title{
Graphical Abstracts
}

C 2015 Published by Elsevier Ltd.

Address for Correspondence: Dr. Hartmut Jaeschke, University of Kansas Medical Center, Department of Pharmacology, Toxicology \& Therapeutics, 3901 Rainbow Blvd, MS 1018, Kansas City, KS 66160 USA, hjaeschke@kumc.edu, Tel: +1 913588 7969, Fax: +1 9135887501 .

*These authors contributed equally to this study

Publisher's Disclaimer: This is a PDF file of an unedited manuscript that has been accepted for publication. As a service to our customers we are providing this early version of the manuscript. The manuscript will undergo copyediting, typesetting, and review of the resulting proof before it is published in its final citable form. Please note that during the production process errors may be discovered which could affect the content, and all legal disclaimers that apply to the journal pertain.

CONFLICT OF INTEREST STATEMENT

The authors declare that there are no conflicts of interest. 


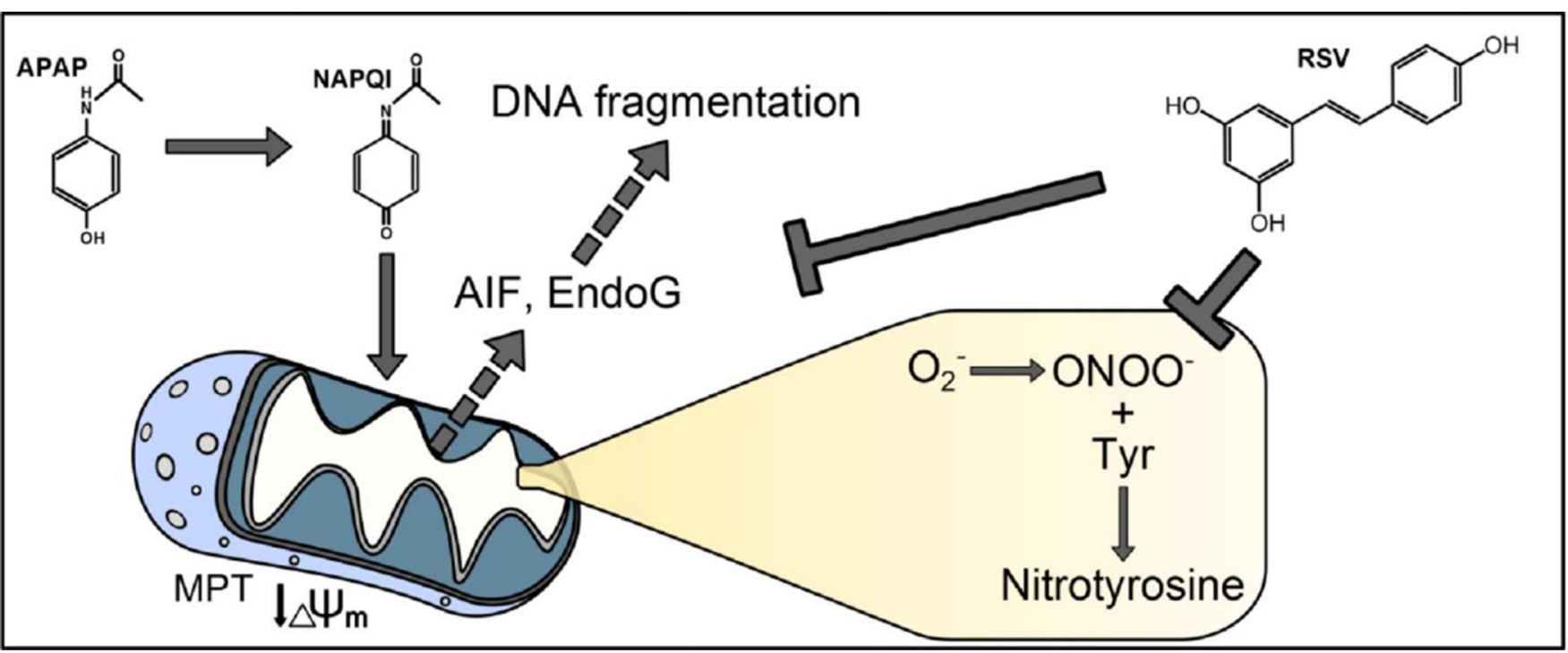

\section{Keywords}

Acetaminophen; resveratrol; drug hepatotoxicity; oxidant stress; DNA fragmentation; mitochondrial dysfunction

\section{INTRODUCTION}

Acetaminophen (APAP) is an analgesic and antipyretic drug that is widely used in Western countries. While it is safe at therapeutic doses, overdose can cause acute liver injury and liver failure (Budnitz et al., 2011; Larson et al., 2005). The toxicity of APAP is initiated by the formation of a reactive metabolite, NAPQI, which can deplete glutathione and bind to cellular proteins, especially proteins in mitochondria (Tirmenstein et al., 1989). The mitochondrial protein binding disturbs the normal respiration of the mitochondria (Meyers et al., 1988) and enhances the formation of reactive oxygen species (ROS) (Jaeschke, 1990) and peroxynitrite (Hinson et al., 1998; Cover et al., 2005). The resulting oxidative stress activates the c-jun N-terminal kinases (JNK) 1/2 (Gunawan et al., 2006; Hendersen et al., 1997; Saito et al., 2010a). JNK activation seems to involve several upstream kinases, including apoptosis signal regulating kinase 1 (Nakagawa et al., 2008), glycogen synthase kinase $3 \beta$ (Shinohara et al., 2010), mixed lineage kinase 3 (Sharma et al., 2012), and possibly the receptor interacting protein kinase 3 (Ramachandran et al., 2013). Activated JNK then translocates to the mitochondria and eventually triggers the opening of the mitochondrial membrane permeability transition (MPT) pore (Hanawa et al., 2008; Kon et al., 2004; Masubuchi et al., 2005). This results in mitochondrial dysfunction and release of mitochondrial intermembrane proteins. In particular, apoptosis-inducing factor (AIF) and endonuclease $\mathrm{G}$ (EndoG) are released and translocate to the nucleus where they cause nuclear DNA fragmentation (Bajt et al., 2006, 2011). The extensive mitochondrial dysfunction and nuclear DNA damage leads to necrotic cell death (Gujral et al., 2002). Importantly, emerging evidence suggests that these mechanisms are also relevant for the 
pathophysiology of APAP-induced liver injury in humans (McGill et al., 2012a; 2014; Xie et al., 2014).

The use of natural products in the prevention and treatment of liver diseases has gained considerable popularity (Zhang et al., 2013; Nair et al., 2014; Jaeschke et al., 2011; 2013). Among these products, resveratrol (RSV), a natural polyphenolic compound primarily found in the skin of grapes, is particularly well-studied (Bishayee et al, 2010). It has been shown to protect against liver damage caused by hepatic ischemia-reperfusion (Hassan-Khabbar et al., 2008; 2010; Plin et al., 2005), ethanol toxicity (Ajmo et al., 2008; Min et al., 2008), high fat diet (Ahn et al., 2008) and hepatotoxic agents such as APAP (Masubuchi et al., 2009; Sener et al., 2006) and carbon tetrachloride (Rivera et al., 2008). The mechanisms that have been proposed to explain this protection include antioxidant effects, up-regulation of anti-oxidant enzymes, modulation of inflammatory responses, and induction of mitochondrial biogenesis (Lagouge et al., 2006; Baur et al., 2006; Sener et al., 2006; Masubuchi et al., 2009; Bishayee et al, 2010). The first group to examine the effect of RSV in APAP-induced liver injury concluded that it protected by acting as an antioxidant, preventing lipid peroxidation (LPO) and possibly neutrophil infiltration (Sener et al., 2006). A more recent study suggested that RSV protected by lowering expression of the pro-inflammatory cytokine TNF-a (Masubuchi et al., 2009). However, these mechanisms are in conflict with other data. For example, it has been clearly demonstrated that the low level of LPO caused by APAP is not critical for the liver injury (Knight et al., 2003). Furthermore, there is considerable evidence that the sterile inflammatory response after APAP does not contribute to the liver injury phase in mice or humans (Cover et al., 2006; Williams et al., 2010a; 2010b; 2011; 2014; Xie et al., 2013), although it may be needed for later recovery and regeneration (Jaeschke et al., 2012; Holt et al., 2008). In addition, neither of these studies examined the effect of RSV on metabolic activation of APAP (i.e. NAPQI formation), which is an essential prerequisite for mechanistic investigation of any intervention in this model (Jaeschke et al., 2011; 2013). Finally, several critical events in the initiation and progression of APAP hepatotoxicity, including JNK activation and mitochondrial translocation, mitochondrial dysfunction, protein nitration, and nuclear DNA fragmentation were not investigated. Thus, the aim of the current study was to explore the effects of RSV treatment on these important mechanisms in APAP hepatotoxicity.

\section{MATERIALS AND METHODS}

\subsection{Animals}

Male C57Bl/6 mice (8-12 weeks old) were purchased from Jackson Laboratories (Bar Harbor, ME) and housed in an environmentally controlled room with a $12 \mathrm{~h}$ light/dark cycle and free access to food and water. All experiments followed the criteria of the National Research Council for the care and use of laboratory animals and were approved by the Institutional animal Care and Use Committee of the University of Kansas Medical Center.

\subsection{In vivo experiments}

Mice were fasted overnight, then injected i.p. with $300 \mathrm{mg}$ APAP/kg body weight. APAP (Sigma, St Louis, MO) was dissolved in warm saline. At $1.5 \mathrm{~h}$ post-APAP, some animals 
were i.p. injected with $50 \mathrm{mg} / \mathrm{kg}$ trans-resveratrol (RSV) (Cayman, Ann Arbor, MI) dissolved in $40 \%$ dimethyl sulfoxide (DMSO) in saline or with the vehicle alone $(1.2 \mathrm{~mL} /$ $\mathrm{kg}$ ). Mice were euthanized at $0,6,24$ or $48 \mathrm{~h}$ post-APAP and blood and livers were harvested. Blood was drawn from the caudal vena cava into a heparinized syringe and centrifuged to obtain plasma. The right and caudate liver lobes were used for isolation of mitochondria, as previously described (Xie et al., 2013). One portion from the left lateral lobe was fixed in $10 \%$ phosphate-buffered formalin for histology, and the remaining pieces were flash frozen and stored at $-80^{\circ} \mathrm{C}$ for later analysis.

\subsection{In vitro experiments}

Primary mouse hepatocytes were isolated as previously described (Bajt et al., 2004). After a short incubation period to allow attachment to the culture dish, the cells were washed and treated with $5 \mathrm{mM}$ APAP dissolved in the culture medium. Some cells were co-treated with either $100 \mu \mathrm{M}$ RSV or DMSO vehicle and the cells were harvested at $0,4.5$ or $8.5 \mathrm{~h}$ postAPAP.

\subsection{Biochemical assays}

Plasma alanine aminotransferase (ALT) activity was measured using a kit, according to the manufacturer's instruction (Pointe Scientific, MI). Lactate dehydrogenase activity (LDH) was measured as previously described (Xie et al., 2013). The JC-1 assay was performed using a kit, according to the manufacturer's instructions (Cell Technology, Fremont, CA). Assays for hepatic GSH and GSSG levels were performed using a modified Tietze assay, as previously described (Jaeschke and Mitchell, 1990). Real time-PCR for mRNA quantification was performed as previously described (Saito et al., 2010b). APAP-protein adducts were measured in liver tissues and mitochondrial pellets as described (Ni et al., 2012b; McGill et al., 2012b).

\subsection{Western Blotting}

Western blotting was performed, as previously described (Bajt et al., 2000). The primary antibodies were rabbit anti-JNK and anti-phospho-JNK antibodies (Cell Signaling Technology, Danvers, MA), rabbit anti-Bax polyclonal antibody (Cell Signaling Technology, Danvers, MA), rabbit anti-AIF antibody (Cell Signaling Technology, Danvers, MA), rabbit anti-EndoG (ProSci, Poway, CA) and rabbit anti-nitrotyrosine (Upstate, Lake Placid, NY). A horseradish peroxidase-coupled anti-rabbit IgG (Santa Cruz) was used as secondary antibody.

\subsection{Histology and immunohistochemistry}

Formalin-fixed liver tissues were embedded in paraffin and $5 \mu \mathrm{m}$ thick sections were cut. Hematoxylin and eosin (H\&E) staining was performed for evaluation of tissue necrosis (Gujral et al., 2002). Nitrotyrosine staining was performed for assessment of nitrotyrosine (NT) protein adducts, as previously described (Knight et al., 2002), using the Dako LSAB peroxidase kit (Dako, Carpinteria, CA) and a rabbit polyclonal anti-nitrotyrosine antibody (Life Technologies, Grand Island, NY). Terminal deoxynucleotidyl transferase-mediated dUTP nick-end labeling (TUNEL) assay was performed for DNA strand break assessment 
with the In Situ Cell Death Detection Kit, AP (Roche Diagnostics, Indianapolis, IN), as described in the manufacturer's instructions.

\subsection{Statistics}

All data were expressed as mean \pm SE. For normally distributed data, statistical significance was evaluated by one-way analysis of variance (ANOVA), followed by Student NewmanKeuls' test. When the data were not normally distributed, ANOVA was performed on ranks, followed by Dunn's multiple comparisons. $\mathrm{P}<0.05$ was considered significant.

\section{RESULTS}

\subsection{RSV protects against APAP hepatotoxicity}

To confirm that RSV protects against APAP hepatotoxicity, mice were treated with 300 $\mathrm{mg} / \mathrm{kg}$ APAP followed by $50 \mathrm{mg} / \mathrm{kg}$ RSV $1.5 \mathrm{~h}$ later and plasma and livers were collected at $0,6,24$, and $48 \mathrm{~h}$ post-APAP. Consistent with earlier reports, plasma ALT activities were significantly lower in the RSV-treated animals compared to vehicle-treated animals at all time points (Fig. 1A). Similarly, RSV-treated mice had less evidence of necrosis in H\&Estained histology sections (Fig. 1B).

\subsection{RSV does not interfere with protein binding but does reduce protein nitration}

To determine whether RSV affects the metabolic activation of APAP, we next measured APAP-protein adducts at $6 \mathrm{~h}$. There was no difference in adduct levels in either total liver homogenates or in mitochondrial fractions (Fig. 2), suggesting that RSV does not inhibit NAPQI formation or protein binding when administered $1.5 \mathrm{~h}$ after APAP. Consistent with this, there was also no difference in GSH depletion and recovery between vehicle and RSVtreated mice at 6 and $24 \mathrm{~h}$ post-APAP (Fig. 3A). However, there were lower glutathione disulfide (GSSG) levels and a reduction in the GSSG-to-GSH ratio at $24 \mathrm{~h}$ (Fig. 3B). Although these data could suggest that RSV has antioxidant effects, it is difficult to determine whether or not the reduced GSSG at this late time point is a cause or a consequence of the protection. To further test this, we performed immunostaining for nitrotyrosine in the liver at $6 \mathrm{~h}$ post-APAP (Fig. 3C). Protein tyrosine nitration is thought to result from peroxynitrite $\left(\mathrm{ONOO}^{-}\right)$formed within mitochondria as a result of superoxide $\left(\mathrm{O}_{2}^{-}\right)$reacting with nitric oxide (NO) during APAP hepatotoxicity. Importantly, livers from RSV-treated animals stained much less strongly for nitrotyrosine (Fig. 3C) and lower nitrotyrosine levels were seen by western blotting (Fig. 3D). These data are consistent with the hypothesis that RSV may serve as a direct antioxidant at early time points. A number of natural products have been shown to induce expression of antioxidant genes (Wu et al., 2014). To determine whether or not RSV also prevents oxidative stress by inducing a stress response, we measured expression of several known Nrf2 targets and other antioxidant genes, namely the catalytic subunit of glutamate cysteine ligase (Gclc), heme oxygenase-1 (Ho-1), catalase, superoxide dismutases (Sod) 1 and 2, and metallothioneins 1 and 2 by RTPCR. Although most of these genes were induced by APAP, none were further induced by RSV co-treatment (Table 1). Thus, the antioxidant effects of RSV did not involve the selective induction of antioxidant genes. 


\subsection{RSV does not affect JNK activation or the MPT}

Because JNK activation during APAP hepatotoxicity is thought to require oxidative stress, we next measured JNK phosphorylation in these animals. Surprisingly, despite the reduced protein nitration, we did not observe a decrease in either activation or mitochondrial translocation of JNK between the vehicle and RSV-treated mice (Fig. 4). In fact, JNK activation appeared to be higher after RSV compared with vehicle treatment. The latter was not an effect of the RSV vehicle, as DMSO did not affect JNK activation or translocation (Suppl. Fig. 1). It is generally accepted that JNK translocation is a critical step in the mitochondrial dysfunction caused by APAP. To determine whether or not mitochondrial dysfunction was prevented by RSV despite the similar JNK activation, primary mouse hepatocytes were co-treated with $5 \mathrm{mM}$ APAP and either vehicle or $100 \mu \mathrm{M} \mathrm{RSV}$, and the mitochondrial membrane potential was assessed using the JC-1 assay. We found that RSV provided complete protection against APAP-induced cell death (Fig. 5A) without preventing the loss of the mitochondrial membrane potential (Fig. 5B). Mitochondrial membrane potential declined as early as $4.5 \mathrm{~h}$ post-treatment and remained low to at least $8.5 \mathrm{~h}$. Interestingly, RSV alone actually caused a transient loss of the membrane potential, with recovery by 8.5 post-treatment (Fig.5B). These data show that, although RSV reduces oxidative stress in this model of APAP toxicity, the extent of the reduction may not be enough to prevent mitochondrial dysfunction.

\subsection{RSV prevents release of endonucleases from mitochondria}

To determine whether or not RSV affects release of endonucleases from the mitochondria and the resulting nuclear DNA fragmentation, AIF and EndoG release into the cytosol were measured by western blotting and TUNEL staining was performed in tissue sections. Interestingly, although RSV did not prevent mitochondrial JNK translocation in vivo or the loss of the mitochondrial membrane potential in vitro, it reduced both the release of these endonucleases from mitochondria (Fig. 6A) and nuclear DNA fragmentation (Fig. 6B). Because Bax has been shown to be responsible for release of AIF from mitochondria at early time points in APAP hepatotoxicity (Bajt et al., 2008), we next measured translocation of Bax into mitochondria. Surprisingly, there was no difference in mitochondrial Bax translocation between vehicle and RSV-treated animals (Fig. 6A). These data suggest that RSV protects against APAP hepatotoxicity, in part, by inhibiting Bax-independent release of AIF and EndoG from mitochondria and preventing nuclear DNA fragmentation. Interestingly, we found that treatment with DMSO vehicle alone caused a minor increase in endonuclease release as well (Suppl. Fig. 1). Thus, the fact that RSV completely prevented AIF release and reduced EndoG release after treatment with APAP and the RSV vehicle further supports the idea that RSV is an effective inhibitor of endonuclease release.

\section{DISCUSSION}

The objective of the current investigation was to evaluate the mechanisms of protection of RSV against APAP hepatotoxicity. Previous work has shown that RSV can prevent LPO and inflammation during APAP hepatotoxicity. However, those earlier studies failed to test the effects of RSV on critical upstream events in the basic pathophysiology of APAPinduced liver injury. In contrast, our data suggest that the delayed administration of RSV did 
not affect protein adduct formation but appeared to protect by scavenging peroxynitrite and by preventing nuclear DNA fragmentation through inhibiting release of the endonucleases AIF and EndoG from mitochondria.

\subsection{Resveratrol as direct scavenger of peroxynitrite}

Several groups have provided evidence for peroxynitrite formation during APAP-induced liver injury (Hinson et al, 1998; Knight et al., 2001) and follow-up studies have demonstrated that peroxynitrite is indeed a critical cytotoxic mediator in the pathophysiology (Knight et al., 2002). The oxidant stress is mainly located in mitochondria (Jaeschke, 1990), presumably derived from the impaired respiratory chain (Meyers et al., 1988), and consequently peroxynitrite formation occurs also in mitochondria (Cover et al., 2005). The mitochondrial oxidant stress and peroxynitrite are responsible for the opening of the mitochondrial membrane permeability transition pore (MPT) and necrotic cell death (Kon et al., 2004, 2010). Our data indicated the protective effect of RSV correlated with extensive reduction of nitrotyrosine adducts in the liver at $6 \mathrm{~h}$. Interestingly, there was no significant effect on GSSG formation, which indicated that RSV appeared to mainly scavenge peroxynitrite rather than prevent the oxidant stress during these early time points. In support of this conclusion, RSV did not affect protein adduct formation including adducts in mitochondria and did not affect JNK activation and translocation to mitochondria, which are related to the mitochondrial oxidant stress (Hanawa et al., 2008; Saito et al., 2010a). On the other hand, several studies have shown that RSV can act as a direct scavenger of peroxynitrite. Holthoff et al. (2010) found that RSV prevents serum albumin nitration by 5amino-3-(4-morpholinyl)-1,2,3-oxadiazolium chloride (SIN-1), which is a donor of both NO and $\mathrm{O}_{2}{ }^{-}$and therefore serves as a source of $\mathrm{ONOO}^{-}$, with an $\mathrm{EC}_{50}$ of $\sim 23 \mu \mathrm{M}$. Importantly, they also observed that RSV could prevent nitrotyrosine formation in cultured cells at concentrations similar to the one used in our study (Holthoff et al., 2010). These data were confirmed by another group (Yang et al., 2012). Although it has been reported that RSV can induce expression of endogenous antioxidant genes (Surh et al., 2008), we were unable to reproduce this in our model. Our findings are more consistent with a recent report showing that RSV failed to induce expression of Nrf2-dependent antioxidant response genes in a high-throughput screening study (Wu et al., 2014). Thus, our data support the hypothesis that RSV protected in vivo mainly by directly scavenging peroxynitrite.

\subsection{Mitochondrial dysfunction and DNA fragmentation}

Due to a lack of caspase activation, caspase-activated DNase cannot be involved in nuclear DNA damage during APAP hepatotoxicity (Jaeschke et al., 2006). Instead it was shown that DNA fragmentation is linked to mitochondrial dysfunction (Cover et al., 2005). More specifically, AIF and EndoG are released from the intermembrane space of mitochondria into the cytosol and translocate to the nucleus to induce DNA damage (Bajt et al., 2006) and generate DNA fragments of various sizes (Cover et al., 2005; Jahr et al., 2001). Importantly, preventing DNA fragmentation reduces the injury (Bajt et al., 2008; 2011). Release of both endonucleases appears to require two steps: the formation of a pore in the outer mitochondrial membrane, and proteolytic cleavage of the inner-membrane-anchored $\mathrm{N}$ terminus of AIF (Arnoult et al., 2003; Otera et al., 2005). The issue of what protease is responsible for the latter is controversial. Conflicting reports suggest that the enzyme is a 
caspase (Arnoult et al., 2003), a calpain (Polster et al., 2005; Chen et al., 2011), or a mitochondrial processing peptidase (Otera et al., 2005). In any case, it has been proposed that AIF release, in particular, occurs in two phases during APAP-induced liver injury: an early phase (1-2 h) mediated by Bax, and a late phase ( $>6 \mathrm{~h}$ ) mediated either by the MPT or through some other unknown mechanism (Bajt et al., 2008). Because RSV did not affect mitochondrial Bax translocation, inhibition of AIF and EndoG release by RSV was unlikely caused by reduced Bax pore formation. However, effective scavenging of peroxynitrite prevented cell necrosis, which involves the MPT and mitochondrial swelling (Kon et al., 2004, 2010; Masubuchi et al., 2005). Thus, the likely reason for the reduced release of mitochondrial intermembrane proteins after RSV treatment was the inhibition of the MPT by removing peroxynitrite as a major trigger. This conclusion does not contradict the observation that RSV protected in vitro without preventing the early depolarization of mitochondria. In fact, a temporary, reversible mitochondrial depolarization has been shown during APAP hepatotoxicity (Hu et al., 2011).

\subsection{Alternate mitochondrial effects of RSV}

RSV has been reported to have indirect effects on mitochondria as well. It has been shown to enhance mitochondrial biogenesis through Sirt1, which activates PGC-1a, the coactivator of the nuclear respiratory factor (Nrf) proteins that control mitochondrial biogenesis (Komen and Thorburn, 2014). RSV can also induce autophagy (Ni et al., 2013), which removes damaged mitochondria from hepatocytes during APAP-induced liver injury (Ni et al., 2012a). However, we were unable to detect any differences in the hepatic content of mitochondrial biogenesis or autophagy markers between vehicle and RSV-treated animals (Du et al., unpublished data), suggesting that neither were responsible for the protection by RSV. There is also some evidence that RSV can affect mitochondrial respiration and reactive oxygen species production by altering the acetylation status of electron transport chain proteins in cardiac issue (Shinmura et al., 2011). It is possible that a similar effect could also contribute to the protection that we observed with RSV in APAP hepatotoxicity.

It is important to point out that many studies using natural products fail to assess the effect of a compound or its vehicle (for example, DMSO, which is a known cytochrome P450 inhibitor) on the metabolism of APAP to its reactive metabolite (Jaeschke et al., 2011, 2013). Reactive metabolite formation and APAP-protein binding are critical initiating events in the mechanisms of APAP-induced liver injury. Anything that interferes with the protein binding will affect the toxicity (Jaeschke et al., 2011, 2013). In this study, we administered RSV 1.5 post-APAP, which is sufficiently late to avoid interfering with APAP biotransformation to its reactive metabolite and the resulting protein binding, which are complete by this time (McGill et al., 2013). Moreover, we found that RSV post-treatment did not affect APAP-protein adduct formation. Thus, we can reasonably conclude that RSV did not alter APAP metabolism in our experiments.

\subsection{Effect of RSV on sterile inflammation}

It was suggested that RSV protected against APAP-induced liver injury because of its antiinflammatory effects (Masubuchi et al., 2009; Sener et al., 2006). Although there is consensus in the literature that APAP hepatotoxicity triggers an extensive sterile 
inflammatory response with cytokine formation and neutrophil recruitment (Cover et al., 2006; Williams et al., 2010a, 2010b), the pathophysiological relevance of inflammation is controversial (Jaeschke et al., 2012). Sterile inflammation is critically dependent on the release of damage associated molecular patterns (DAMPs) from necrotic cells. Thus, a reduction in cell necrosis will attenuate DAMP release and consequently reduce proinflammatory cytokine formation and neutrophil infiltration (Xie et al., 2013). One of the previous studies showed RSV partially protected against APAP toxicity with reduced neutrophil accumulation at $4 \mathrm{~h}$ (Sener et al., 2009). However, the $4 \mathrm{~h}$ time point is very early during the injury phase and DAMP release making it likely that the reduced injury was the cause of the lower neutrophil infiltration. The second study also showed only a correlation between less liver injury in the RSV-treated group and reduced hepatic TNF-a mRNA expression (Masubuchi et al., 2009). Thus, none of these studies actually demonstrated a direct anti-inflammatory effect of RSV. Together, the preponderance of experimental evidence argues against inflammation being a major contributor to APAP-induced liver injury in experimental animals (Jaeschke et al., 2012) and in humans (Antoniades et al., 2012; Williams et al., 2014).

\subsection{Summary and conclusions}

In summary, our data suggest that therapeutic administration of RSV protects against APAPinduced liver injury by scavenging peroxynitrite and by preventing AIF and EndoG release from mitochondria and the subsequent nuclear DNA fragmentation. These findings are in contrast to previously reported mechanisms of RSV-mediated protection and illustrate the importance of considering all steps in the basic pathophysiology of APAP toxicity. Importantly, our data strongly emphasize that RSV may be a valid treatment option for APAP overdose.

\section{Supplementary Material}

Refer to Web version on PubMed Central for supplementary material.

\section{ACKNOWLEDGEMENTS}

This investigation was supported in part by the National Institutes of Health grants R01 DK070195 and R01 AA12916 to H.J., and by grants from the National Center for Research Resources (5P20RR021940-07) and the National Institute of General Medical Sciences (8 P20 GM103549-07) from the National Institutes of Health. Additional support came from the "Training Program in Environmental Toxicology" T32 ES007079-26A2 (to M.R.M.) from the National Institute of Environmental Health Sciences.

\section{Abbreviations}
AIF
apoptosis-inducing factor
ALT
alanine aminotransferase
APAP acetaminophen
DAMP damage associated molecular pattern
DMSO dimethyl sulfoxide 


$\begin{array}{ll}\text { EndoG } & \text { endonuclease G } \\ \text { GSH } & \text { glutathione } \\ \text { GSSG } & \text { glutathione disulfide } \\ \text { gclc } & \text { Glutamate-cysteine ligase, catalytic subunit } \\ \text { H\&E } & \text { hematoxilin\& ampeosin } \\ \text { Ho-1 } & \text { heme oxygenase 1 } \\ \text { JNK } & \text { c-Jun N-terminal kinase } \\ \text { LDH } & \text { lactate dehydrogenase } \\ \text { LPO } & \text { lipid peroxidation } \\ \text { MPT } & \text { mitochondrial membrane permeability transition } \\ \text { Mt } & \text { metallothionein } \\ \text { NAPQI } & N \text {-acetyl- } p \text {-benzoquinone imine } \\ \text { RSV } & \text { resveratrol } \\ \text { SOD } & \text { superoxide dismutase }\end{array}$

TUNEL terminal deoxynucleotidyl transferase-mediated dUTP nick-end labeling assay

\section{REFERENCES}

Ahn J, Cho I, Kim S, Kwon D, Ha T. Dietary resveratrol alters lipid metabolism-related gene expression of mice on an atherogenic diet. J. Hepatol. 2008; 49:1019-1028. [PubMed: 18930334]

Ajmo JM, Liangm X, Rogers CQ, Pennock B, You M. Resveratrol alleviates alcoholic fatty liver in mice. Am. J. Physiol. Gastrointest. Liver Physiol. 2008; 295:G833-G842. [PubMed: 18755807]

Antoniades CG, Quaglia A, Taams LS, Mitry RR, Hussain M, Abeles R, Possamai LA, Bruce M, McPhail M, Starling C, Wagner B, Barnardo A, Pomplun S, Auzinger G, Bernal W, Heaton N, Vergani D, Thursz MR, Wendon J. Source and characterization of hepatic macrophages in acetaminophen-induced acute liver failure in humans. Hepatology. 2012; 56:735-746. [PubMed: 22334567]

Arnoult D, Gaume B, Karbowski M, Sharpe JC, Cecconi F, Youle RJ. Mitochondrial release of AIF and EndoG requires caspase activation downstream of Bax/Bak-mediated permeabilization. EMBO J. 2003; 22:4385-4399. [PubMed: 12941691]

Bajt ML, Cover C, Lemasters JJ, Jaeschke H. Nuclear translocation of endonuclease G and apoptosisinducing factor during acetaminophen-induced liver injury. Toxicol. Sci. 2006; 94:217-225. [PubMed: 16896059]

Bajt ML, Farhood A, Lemasters JJ, Jaeschke H. Mitochondrial bax translocation accelerates DNA fragmentation and cell necrosis in a murine model of acetaminophen hepatotoxicity. J. Pharmacol. Exp. Ther. 2008; 324:8-14. [PubMed: 17906064]

Bajt ML, Knight TR, Lemasters JJ, Jaeschke H. Acetaminophen-induced oxidant stress and cell injury in cultured mouse hepatocytes: protection by N-acetyl cysteine. Toxicol. Sci. 2004; 80:343-349. [PubMed: 15115886]

Bajt ML, Lawson JA, Vonderfecht SL, Gujral JS, Jaeschke H. Protection against Fas receptormediated apoptosis in hepatocytes and nonparenchymal cells by a caspase- 8 inhibitor in vivo: evidence for a postmitochondrial processing of caspase-8. Toxicol. Sci. 2000; 58:109-117. [PubMed: 11053547] 
Bajt ML, Ramachandran A, Yan HM, Lebosfky M, Farhood A, Lemasters JJ, Jaeschke H. Apoptosisinducing factor modulates mitochondrial oxidant stress in acetaminophen hepatotoxicity. Toxicol. Sci. 2011; 122:598-605. [PubMed: 21572097]

Baur JA, Pearson KJ, Price NL, Jamieson HA, Lerin C, Kalra A, Prabhu VV, Allard JS, Lopez-Lluch G, Lewis K, Pistell PJ, Poosala S, Becker KG, Boss O, Gwinn D, Wang M, Ramaswamy S, Fishbein KW, Spencer RG, Lakatta EG, Le Couteur D, Shaw RJ, Navas P, Puigserver P, Ingram DK, de Cabo R, Sinclair DA. Resveratrol improves health and survival of mice on a high-calorie diet. Nature. 2006; 444:337-342. [PubMed: 17086191]

Bishayee A, Darvesh AS, Politis T, McGory R. Resveratrol and liver disease: from bench to bedside and community. Liver Int. 2010; 30:1103-1114. [PubMed: 20557453]

Budnitz DS, Lovegrove MC, Crosby AE. Emergency department visits for overdoses of acetaminophen-containing products. Am. J. Prev. Med. 2011; 40:585-592. [PubMed: 21565648]

Chen Q, Paillard M, Gomez L, Ross T, Hu Y, Xu A, Lesnefsky EJ. Activation of mitochondrial $\mu$ calpain increases AIF cleavage in cardiac mitochondria during ischemia-reperfusion. Biochem. Biophys. Res. Commun. 2011; 415:533-538. [PubMed: 22057010]

Cover C, Liu J, Farhood A, Malle E, Waalkes MP, Bajt ML, Jaeschke H. Pathophysiological role of the acute inflammatory response during acetaminophen hepatotoxicity. Toxicol. Appl. Pharmacol. 2006; 216:98-107. [PubMed: 16781746]

Cover C, Mansouri A, Knight TR, Bajt ML, Lemasters JJ, Pessayre D, Jaeschke H. Peroxynitriteinduced mitochondrial and endonuclease-mediated nuclear DNA damage in acetaminophen hepatotoxicity. J. Pharmacol. Exp. Ther. 2005; 315:879-887. [PubMed: 16081675]

Gujral JS, Knight TR, Farhood A, Bajt ML, Jaeschke H. Mode of cell death after acetaminophen overdose in mice: apoptosis or oncotic necrosis? Toxicol. Sci. 2002; 67:322-328. [PubMed: 12011492]

Gunawan BK, Liu ZX, Han D, Hanawa N, Gaarde WA, Kaplowitz N. c-Jun N-terminal kinase plays a major role in murine acetaminophen hepatotoxicity. Gastroenterology. 2006; 131:165-178. [PubMed: 16831600]

Hanawa N, Shinohara M, Saberi B, Gaarde WA, Han D, Kaplowitz N. Role of JNK translocation to mitochondria leading to inhibition of mitochondria bioenergetics in acetaminophen-induced liver injury. J. Biol. Chem. 2008; 283:13565-13577. [PubMed: 18337250]

Hassan-Khabbar S, Cottart CH, Wendum D, Vibert F, Clot JP, Savouret JF, Conti M, Nivet-Antoine V. Postischemic treatment by trans-resveratrol in rat liver ischemia-reperfusion: a possible strategy in liver surgery. Liver Transpl. 2008; 14:451-459. [PubMed: 18383089]

Hassan-Khabbar S, Vamy M, Cottart CH, Wendum D, Vibert F, Savouret JF, Thérond P, Clot JP, Waligora AJ, Nivet-Antoine V. Protective effect of post-ischemic treatment with trans-resveratrol on cytokine production and neutrophil recruitment by rat liver. Biochimie. 2010; 92:405-410. [PubMed: 20036306]

Henderson NC, Pollock KJ, Frew J, Mackinnon AC, Flavell RA, Davis RJ, Sethi T, Simpson KJ. Critical role of c-jun (NH2) terminal kinase in paracetamol-induced acute liver failure. Gut. 2007; 56:982-990. [PubMed: 17185352]

Hinson JA, Pike SL, Pumford NR, Mayeux PR. Nitrotyrosine-protein adducts in hepatic centrilobular areas following toxic doses of acetaminophen in mice. Chem. Res. Toxicol. 1998; 11:604-607. [PubMed: 9625727]

Holt MP, Cheng L, Ju C. Identification and characterization of infiltrating macrophages in acetaminophen-induced liver injury. J. Leukoc. Biol. 2008; 84:1410-1421. [PubMed: 18713872]

Holthoff JH, Woodling KA, Doerge DR, Burns ST, Hinson JA, Mayeux PR. Resveratrol, a dietary polyphenolic phytoalexin, is a functional scavenger of peroxynitrite. Biochem. Pharmacol. 2010; 80:1260-1265. [PubMed: 20599800]

Hu JT, Ramshesh VK, Jaeschke H, Lemasters JJ. Intravital multiphoton imaging of low dose acetaminophen toxicity in mouse livers (abstract). Hepatology. 2011; 54(Supplement 1):1250A1251A.

Jaeschke H. Glutathione disulfide formation and oxidant stress during acetaminophen-induced hepatotoxicity in mice in vivo: the protective effect of allopurinol. J. Pharmacol. Exp. Ther. 1990; 255:935-941. [PubMed: 2262912] 
Jaeschke H, Cover C, Bajt ML. Role of caspases in acetaminophen-induced liver injury. Life Sci. 2006; 78:1670-1676. [PubMed: 16226279]

Jaeschke H, Mitchell JR. Use of isolated perfused organs in hypoxia and ischemia/reperfusion oxidant stress. Methods Enzymol. 1990; 186:752-759. [PubMed: 2233332]

Jaeschke H, McGill MR, Williams CD, Ramachandran A. Current issues with acetaminophen hepatotoxicity - a clinically relevant model to test the efficacy of natural products. Life Sci. 2011; 88:737-745. [PubMed: 21296090]

Jaeschke H, Williams CD, McGill MR, Xie Y, Ramachandran A. Models of drug-induced liver injury for evaluation of phytotherapeutics and other natural products. Food Chem. Toxicol. 2013; 55:279-289. [PubMed: 23353004]

Jaeschke H, Williams CD, Ramachandran A, Bajt ML. Acetaminophen hepatotoxicity and repair: the role of sterile inflammation and innate immunity. Liver Int. 2012; 32:8-20. [PubMed: 21745276]

Jahr S, Hentze H, Englisch S, Hardt D, Fackelmayer FO, Hesch RD, Knippers R. DNA fragments in the blood plasma of cancer patients: quantitations and evidence for their origin from apoptotic and necrotic cells. Cancer Res. 2001; 61:1659-1665. [PubMed: 11245480]

Knight TR, Fariss MW, Farhood A, Jaeschke H. Role of lipid peroxidation as a mechanism of liver injury after acetaminophen overdose in mice. Toxicol. Sci. 2003; 76:229-236. [PubMed: 12944590]

Knight TR, Ho YS, Farhood A, Jaeschke H. Peroxynitrite is a critical mediator of acetaminophen hepatotoxicity in murine livers: protection by glutathione. J. Pharmacol. Exp. Ther. 2002; 303:468-475. [PubMed: 12388625]

Knight TR, Kurtz A, Bajt ML, Hinson JA, Jaeschke H. Vascular and hepatocellular peroxynitrite formation during acetaminophen toxicity: role of mitochondrial oxidant stress. Toxicol. Sci. 2001; 62:212-220. [PubMed: 11452133]

Komen JC, Thorburn DR. Turn up the power - pharmacological activation of mitochondrial biogenesis in mouse models. Br. J. Pharmacol. 2014; 171:1818-1836. [PubMed: 24102298]

Kon K, Kim JS, Jaeschke H, Lemasters JJ. Mitochondrial permeability transition in acetaminopheninduced necrosis and apoptosis of cultured mouse hepatocytes. Hepatology. 2004; 40:1170-1179. [PubMed: 15486922]

Kon K, Kim JS, Uchiyama A, Jaeschke H, Lemasters JJ. Lysosomal iron mobilization and induction of the mitochondrial permeability transition in acetaminophen-induced toxicity to mouse hepatocytes. Toxicol. Sci. 2010; 117:101-108. [PubMed: 20584761]

Lagouge M, Argmann C, Gerhart-Hines Z, Meziane H, Lerin C, Daussin F, Messadeq N, Milne J, Lamber P, Elliott P, Geny B, Laakso M, Puiqserver P, Auwerx J. Resveratrol improves mitochondrial function and protects against metabolic disease by activating SIRT1 and PGC-1alpha. Cell. 2006; 127:1109-1122. [PubMed: 17112576]

Larson AM, Polson J, Fontana RJ, Davern TJ, Lalani E, Hynan LS, Reisch JS, Schiødt FV, Ostapowicz G, Shakil AO, Lee WM. Acute Liver Failure Study Group. Acetaminophen-induced acute liver failure: results of a United States multicenter, prospective study. Hepatology. 2005; 42:1364-1372. [PubMed: 16317692]

Masubuchi Y, Suda C, Horie T. Involvement of mitochondrial permeability transition in acetaminophen-induced liver injury in mice. J. Hepatol. 2005; 42:110-116. [PubMed: 15629515]

Masubuchi Y, Sugiyama S, Horie T. Th1/Th2 cytokine balance as a determinant of acetaminopheninduced liver injury. Chem. Biol. Interact. 2009; 179:273-279. [PubMed: 19014921]

McGill MR, Sharpe MR, Williams CD, Taha M, Curry SC, Jaeschke H. The mechanism underlying acetaminophen-induced hepatotoxicity in humans and mice involves mitochondrial damage and nuclear DNA fragmentation. J. Clin. Invest. 2012a; 122:1574-1583. [PubMed: 22378043]

McGill MR, Staggs VS, Sharpe MR, Lee WM, Jaeschke H. Acute Liver Failure Study Group. Serum mitochondrial biomarkers and damage-associated molecular patterns are higher in acetaminophen overdose patients with poor outcome. Hepatology. 2014; 60:1336-1345. [PubMed: 24923598]

McGill MR, Williams CD, Xie Y, Ramachandran A, Jaeschke H. Acetaminophen-induced liver injury in rats and mice: comparison of protein adducts, mitochondrial dysfunction, and oxidative stress in the mechanism of toxicity. Toxicol. Appl. Pharmacol. 2012b; 264:387-394. [PubMed: 22980195] 
Meyers LL, Beierschmitt WP, Khairallah EA, Cohen SD. Acetaminophen-induced inhibition of hepatic mitochondrial respiration in mice. Toxicol. Appl. Pharmacol. 1988; 93:378-387. [PubMed: 3368917]

Min Y, Liang X, Ajmo JM, Ness GC. Involvement of mammalian sitruin 1 in the action of ethanol in the liver. Am. J. Physiol. Gastrointest. Liver Physiol. 2008; 294:G892-G898. [PubMed: 18239056]

Nair DG, Weiskirchen R, Al-Musharafi SK. The use of marine-derived bioactive compounds as potential hepatoprotective agents. Acta Pharmacol. Sin. 2014 [Epub ahead of print].

Nakagawa H, Maeda S, Hikiba Y, Ohmae T, Shibata W, Yanai A, Sakamoto K, Ogura K, Noguchi T, Karin M, Ichijo H, Omata M. Deletion of apoptosis signal-regulating kinase 1 attenuates acetaminophen-induced liver injury by inhibiting c-Jun N-terminal kinase activation. Gastroenterology. 2008; 135:1311-1321. [PubMed: 18700144]

Ni HM, Bockus A, Boggess N, Jaeschke H, Ding WX. Activation of autophagy protects against acetaminophen-induced hepatotoxicity. Hepatology. 2012a; 55:222-232. [PubMed: 21932416]

Ni HM, Boggess N, McGill MR, Lebofsky M, Borude P, Apte U, Jaeschke H, Ding WX. Liverspecific loss of Atg5 causes persistent activation of Nrf2 and protects against acetaminopheninduced liver injury. Toxicol. Sci. 2012b; 127:438-450. [PubMed: 22491424]

Ni HM, Du K, You M, Ding WX. Critical role of FoxO3a in alcohol-induced autophagy and hepatotoxicity. Am. J. Pathol. 2013; 183:1815-1825. [PubMed: 24095927]

Otera H, Ohsakaya S, Nagaura Z, Ishihara N, Mihara K. Export of mitochondrial AIF in response to proapoptotic stimuli depends on processing at the intermembrane space. EMBO J. 2005; 24:13751386. [PubMed: 15775970]

Plin C, Tillement JP, Berdeaux A, Morin D. Resveratrol protects against cold ischemia-warm reoxygenation-induced damages to mitochondrial and cells in rat liver. Eur. J. Pharmacol. 2005; 528:162-168. [PubMed: 16325807]

Polster BM, Basanez G, Etxebarria A, Hardwick JM, Nicholls DG. Calpain I induces cleavage and release of apoptosis-inducing factor from isolated mitochondria. J. Biol. Chem. 2005; 280:64476454. [PubMed: 15590628]

Ramachandran A, McGill MR, Xie Y, Ni HM, Ding WX, Jaeschke H. Receptor interacting protein kinase 3 is a critical early mediator of acetaminophen-induced hepatocyte necrosis in mice. Hepatology. 2013; 58:2099-2108. [PubMed: 23744808]

Rivera H, Shibayama M, Tsutsumi V, Perez-Alvarez V, Muriel P. Resveratrol and trimethylated resveratrol protect from liver damage induced by $\mathrm{CCl}_{4}$ in the rat. J. Appl. Toxicol. 2008; 28:147155. [PubMed: 17541932]

Saito C, Lemasters JJ, Jaeschke H. c-Jun N-terminal kinase modulates oxidant stress and peroxynitrite formation independent of inducible nitric oxide synthase in acetaminophen hepatotoxicity. Toxicol. Appl. Pharmacol. 2010a; 246:8-17. [PubMed: 20423716]

Saito C, Yan HM, Artigues A, Villar MT, Farhood A, Jaeschke H. Mechanism of protection by metallothionein against acetaminophen hepatotoxicity. Toxicol. Appl. Pharmacol. 2010b; 242:182-190. [PubMed: 19835899]

Sener G, Toklu HZ, Sehirli AO, Velioğlu-Oğünç A, Cetinel S, Gedik N. Protective effects of resveratrol against acetaminophen-induced toxicity in mice. Hepatol. Res. 2006; 35:62-68. [PubMed: 16595188]

Sharma M, Gadang V, Jaeschke A. Critical role for mixed-lineage kinase 3 in acetaminophen-induced hepatotoxicity. Mol. Pharmacol. 2012; 82:1001-1007. [PubMed: 22918968]

Shinmura K, Tamaki K, Sano M, Nakashima-Kamimura N, Wolf AM, Amo T, Ohta S, Katsumata Y, Fukuda K, Ishiwata K, Suematsu M, Adachi T. Caloric restriction primes mitochondria for ischemic stress by deacetylating specific mitochondrial proteins of the electron transport chain. Circ. Res. 2011; 109:396-406. [PubMed: 21700931]

Shinohara M, Ybanez MD, Win S, Than TA, Jain S, Gaarde WA, Han D, Kaplowitz N. Silencing glycogen synthase kinase-3beta inhibits acetaminophen hepatotoxicity and attenuates JNK activation and loss of glutamate cysteine ligase and myeloid cell leukemia sequence 1. J. Biol. Chem. 2010; 285:8244-8255. [PubMed: 20061376] 
Surh YJ, Kundu JK, Na HK. Nrf2 as a master redox switch in turning on the cellular signaling involved in the induction of cytoprotective genes by some chemopreventive phytochemicals. Planta Med. 2008; 74:1526-1539. [PubMed: 18937164]

Tirmenstein MA, Nelson SD. Subcellular binding and effects on calcium homeostasis produced by acetaminophen and a nonhepatotoxic regioisomer, 3'-hydroxyacetanilide, in mouse liver. J. Biol. Chem. 1989; 264:9814-9819. [PubMed: 2524496]

Williams CD, Bajt ML, Farhood A, Jaeschke H. Acetaminophen-induced hepatic neutrophil accumulation and inflammatory liver injury in CD18-deficient mice. Liver Int. 2010a; 30:12801292. [PubMed: 20500806]

Williams CD, Bajt ML, Sharpe MR, McGill MR, Farhood A, Jaeschke H. Neutrophil activation during acetaminophen hepatotoxicity and repair in mice and humans. Toxicol. Appl. Pharmacol. 2014; 275:122-133. [PubMed: 24440789]

Williams CD, Farhood A, Jaeschke H. Role of caspase-1 and interleukin-1beta in acetaminopheninduced hepatic inflammation and liver injury. Toxicol. Appl. Pharmacol. 2010b; 247:169-178. [PubMed: 20637792]

Williams CD, Antoine DJ, Shaw PJ, Benson C, Farhood A, Williams DP, Kanneganti TD, Park BK, Jaeschke H. Role of the Nalp3 inflammasome in acetaminophen-induced sterile inflammation and liver injury. Toxicol. Appl. Pharmacol. 2011; 252:289-297. [PubMed: 21396389]

Wu KC, McDonald PR, Liu J, Klaassen CD. Screening of natural compounds as activators of the Keap1-Nrf2 pathway. Planta Med. 2014; 80:97-104. [PubMed: 24310212]

Xie Y, McGill MR, Dorko K, Kumer SC, Schmitt TM, Forster J, Jaeschke H. Mechanisms of acetaminophen-induced cell death in primary human hepatocytes. Toxicol. Appl. Pharmacol. 2014; 279:266-274. [PubMed: 24905542]

Xie Y, Williams CD, McGill MR, Lebofsky M, Ramachandran A, Jaeschke H. Purinergic receptor antagonist A438079 protects against acetaminophen-induced liver injury by inhibiting P450 isoenzymes, not by inflammation activation. Toxicol. Sci. 2013; 131:325-35. [PubMed: 22986947]

Zhang A, Sun H, Wang X. Recent advances in natural products from plants for treatment of liver diseases. Eur. J. Med. Chem. 2013; 63:570-571. [PubMed: 23567947] 


\section{HIGHLIGHTS}

- $\quad$ Resveratrol post-treatment protects against acetaminophen hepatotoxicity

- $\quad$ Resveratrol post-treatment does not affect acetaminophen-protein binding or JNK activation

- $\quad$ Resveratrol reduces oxidative stress and nitrotyrosine staining during acetaminophen toxicity

- $\quad$ Resveratrol reduces release of endonucleases from damaged mitochondria during acetaminophen toxicity 


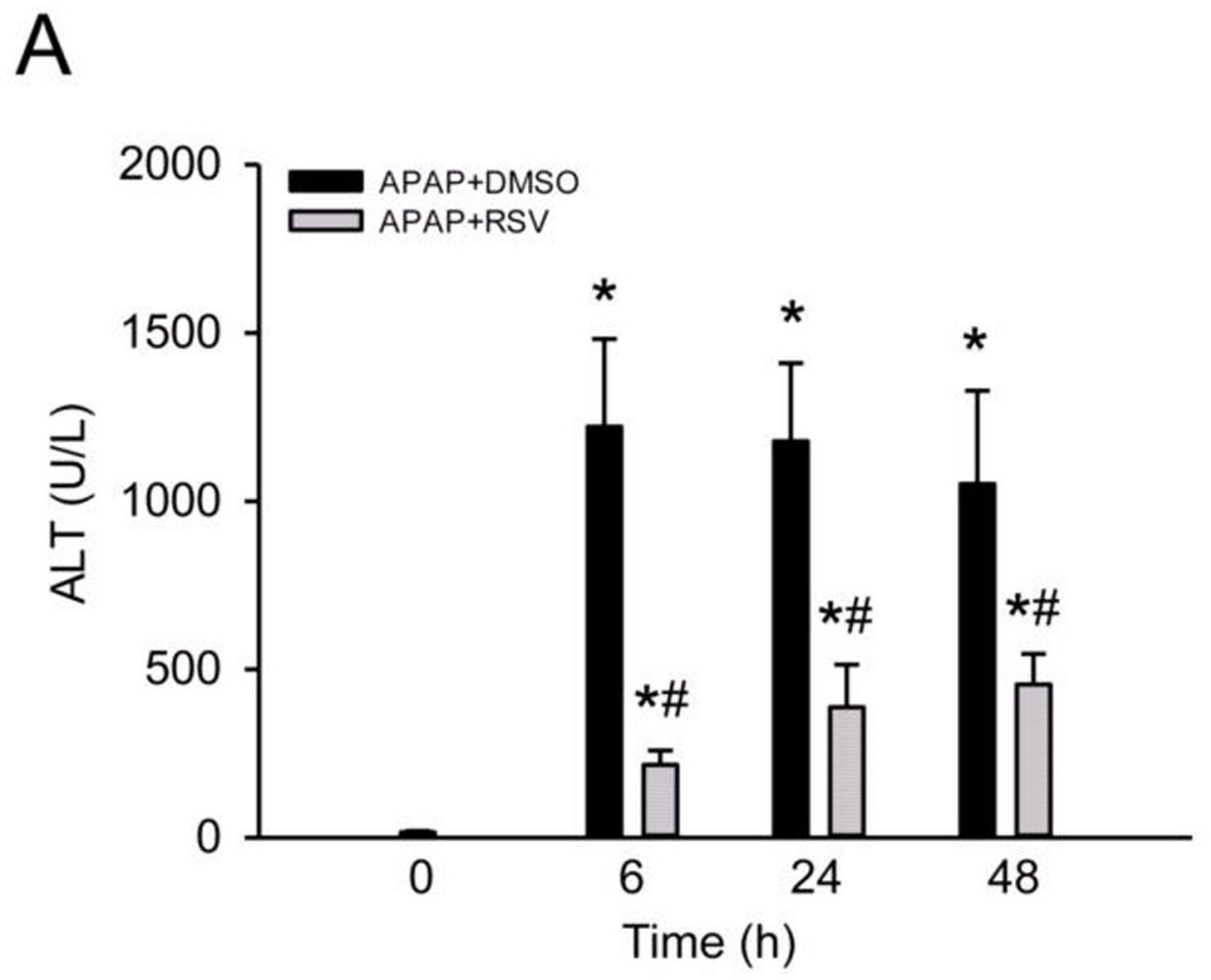

B

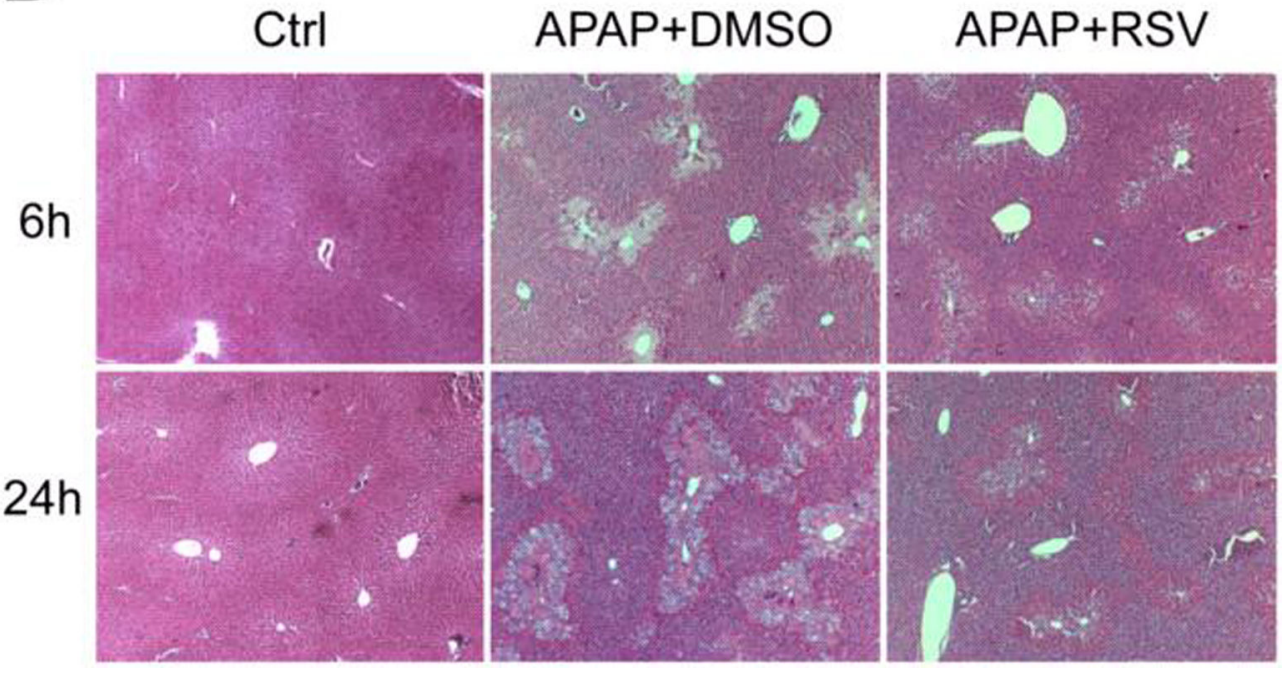

Figure 1. Resveratrol protects against acetaminophen (APAP) hepatotoxicity Mice were treated with $300 \mathrm{mg} / \mathrm{kg}$ APAP followed by dimethyl sulfoxide (DMSO) vehicle or $50 \mathrm{mg} / \mathrm{kg}$ resveratrol (RSV) 1.5h later. Plasma and liver tissue were harvested at the indicated time points post-APAP. (A) Plasma alanine aminotransferase (ALT) activity. (B) $\mathrm{H} \& \mathrm{E}$ stained liver sections. Bars represent means $\pm \mathrm{SEM}$ for $\mathrm{n}=3-6$ mice. $* \mathrm{P}<0.05$ vs. 0h. ${ }^{\#} \mathrm{P}<0.05$ vs. APAP + DMSO treatment. 


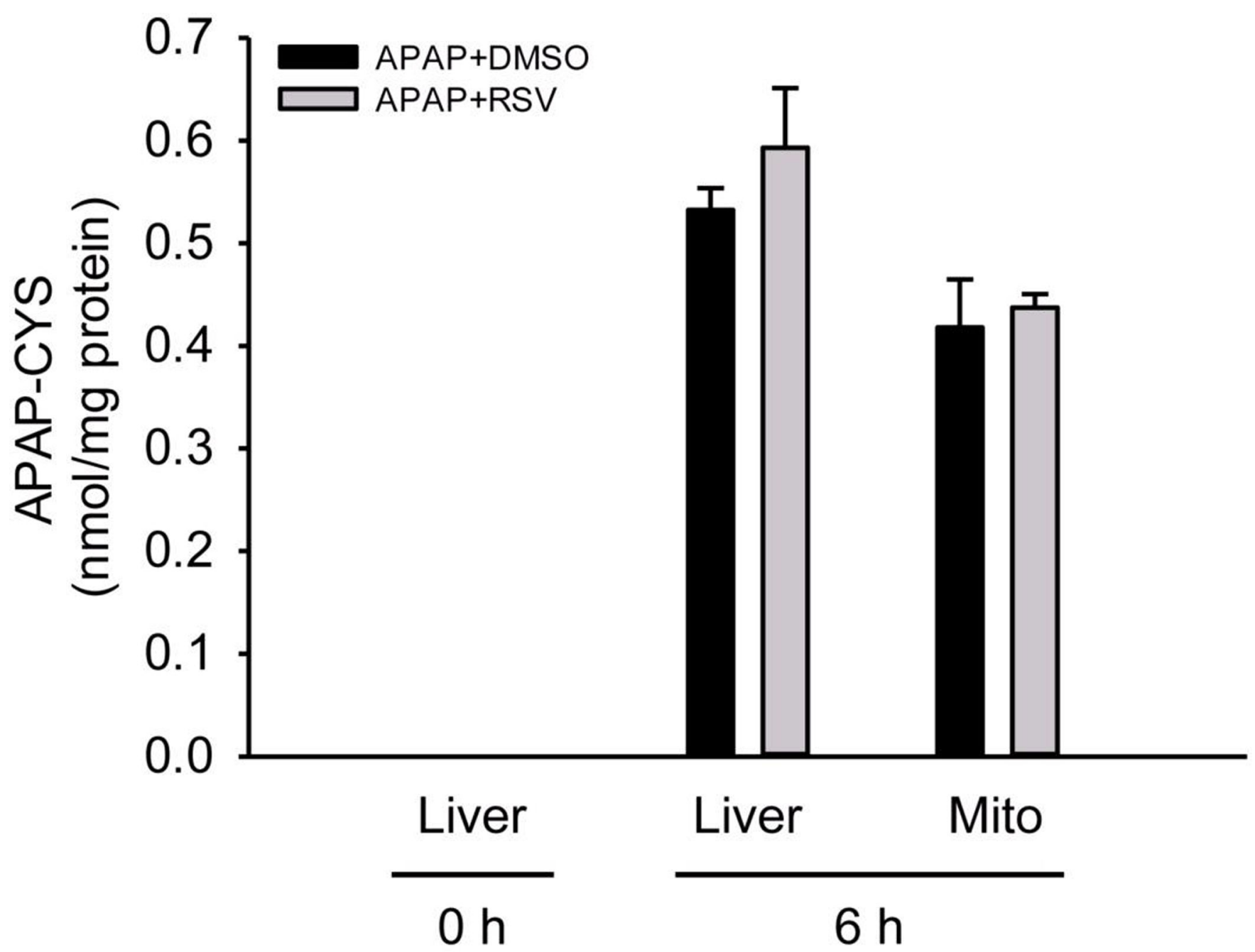

Figure 2. Resveratrol post-treatment does not affect acetaminophen (APAP)-protein binding Mice were treated with $300 \mathrm{mg} / \mathrm{kg}$ APAP followed by dimethyl sulfoxide (DMSO) vehicle or $50 \mathrm{mg} / \mathrm{kg}$ resveratrol (RSV) $1.5 \mathrm{~h}$ later. Liver tissue was harvested at $6 \mathrm{~h}$ post-APAP. APAP-protein adducts were measured in both whole liver homogenates and isolated mitochondrial fractions. Bar graphs show mean \pm SEM for $n=3-6$ mice. 


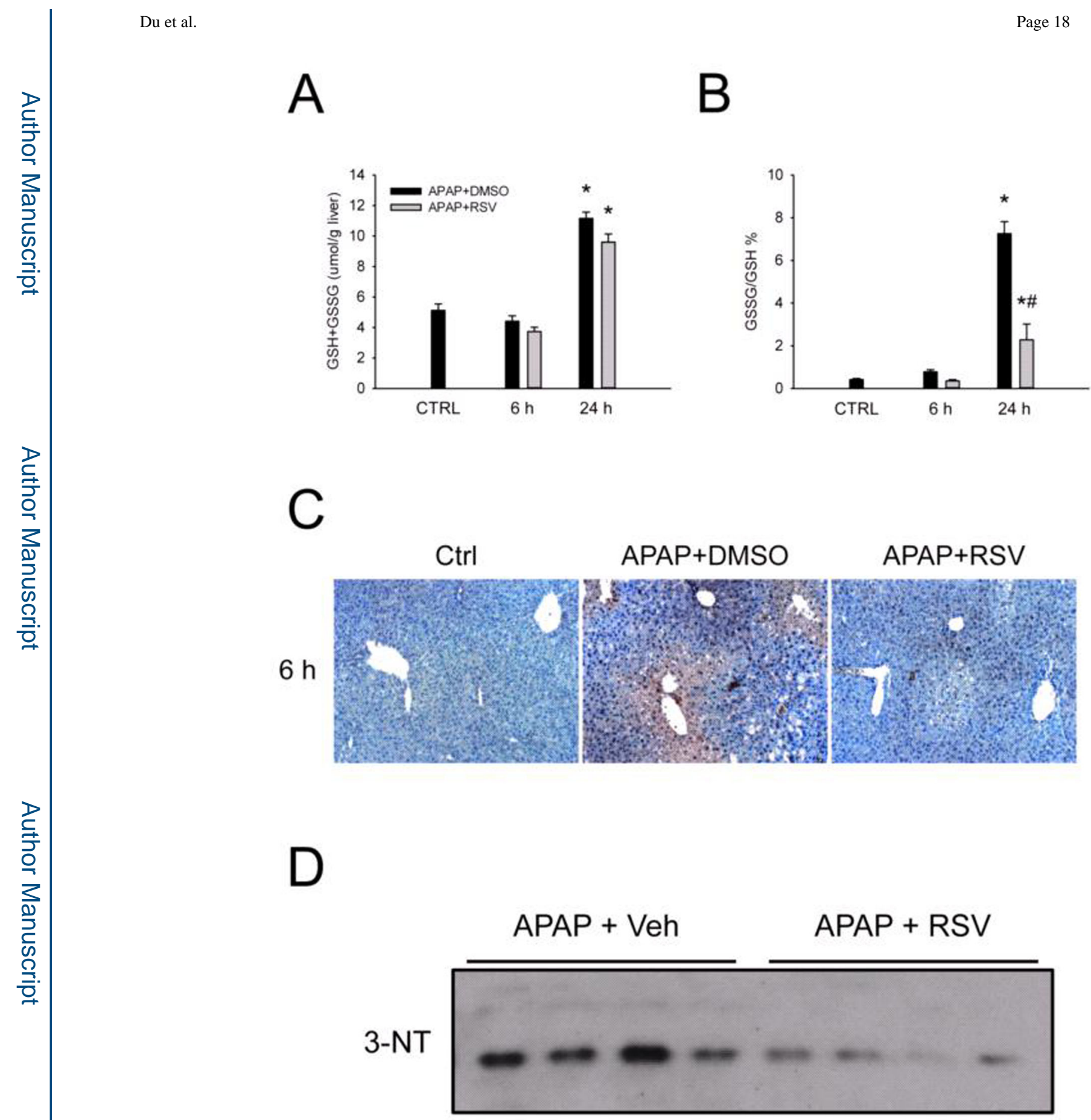

Figure 3. Resveratrol post-treatment does not affect glutathione depletion but does reduce oxidative stress and nitrotyrosine levels in the liver

Mice were treated with $300 \mathrm{mg} / \mathrm{kg}$ acetaminophen (APAP) followed by dimethyl sulfoxide (DMSO) vehicle or $50 \mathrm{mg} / \mathrm{kg}$ resveratrol (RSV) $1.5 \mathrm{~h}$ later. Liver tissue was harvested at the indicated time points post-APAP. (A) Total hepatic glutathione (GSH) levels. (B) The percentage of total GSH in the oxidized form (GSSG). (C) Nitrotyrosine staining of liver tissue sections. (D) Western blot of whole liver homogenate using an anti-nitrotyrosine antibody. Bar graphs show mean \pm SEM for $\mathrm{n}=3-6$ mice. ${ }^{*} \mathrm{P}<0.05$ vs. CTRL. ${ }^{*} \mathrm{P}<0.05$ vs. APAP + DMSO treatment. 
A

Cytosol

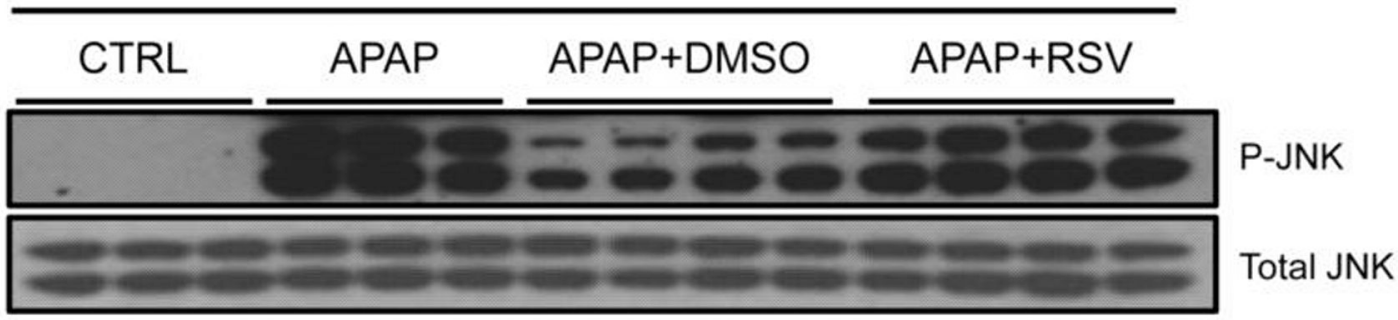

Mitochondria

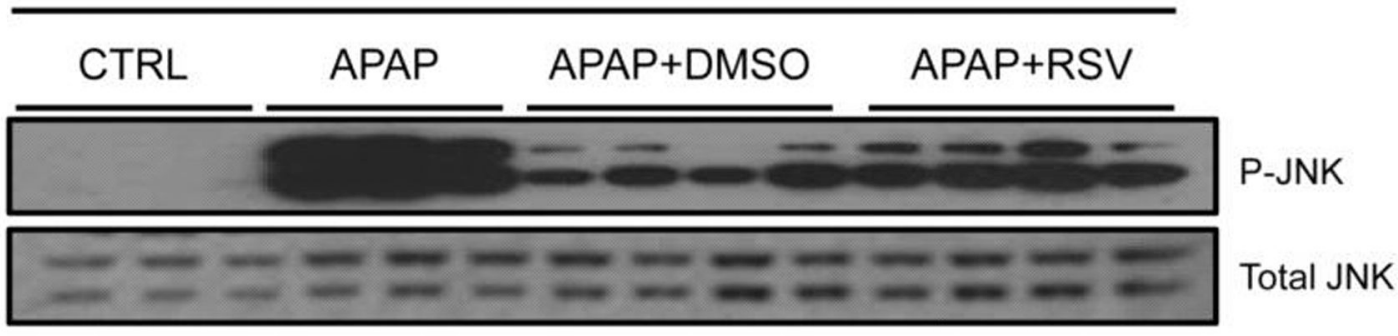

B
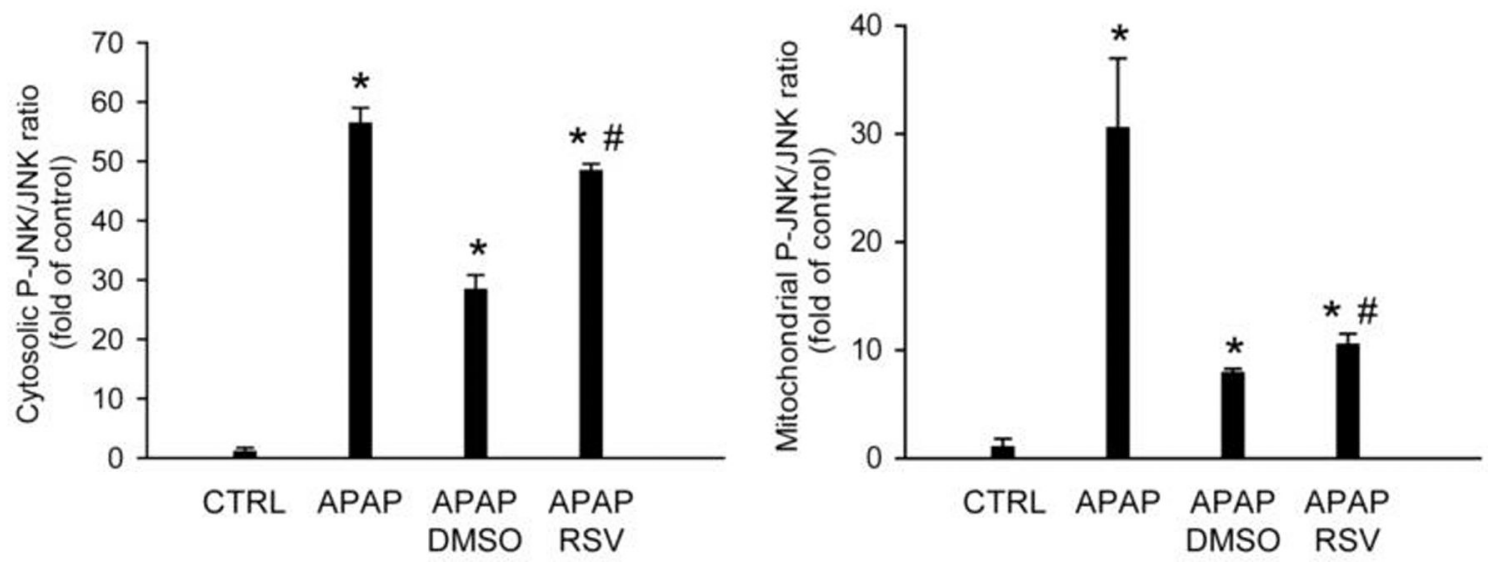

Figure 4. Resveratrol does not prevent c-Jun N-terminal kinase (JNK) activation or mitochondrial translocation

Mice were treated with $300 \mathrm{mg} / \mathrm{kg}$ acetaminophen (APAP) followed by dimethyl sulfoxide (DMSO) vehicle or $50 \mathrm{mg} / \mathrm{kg}$ resveratrol (RSV) $1.5 \mathrm{~h}$ later. (A) Liver tissue was harvested at $6 \mathrm{~h}$ post-APAP and mitochondrial and cytosol fractions were isolated and probed for the total and phosphorylated forms of the c-Jun N-terminal kinases 1/2. (B) Densitometry. Bar graphs show mean \pm SEM for $n=3-4$ mice. ${ }^{*} \mathrm{P}<0.05$ vs. CTRL. ${ }^{*} \mathrm{P}<0.05$ vs. APAP + DMSO treatment. 

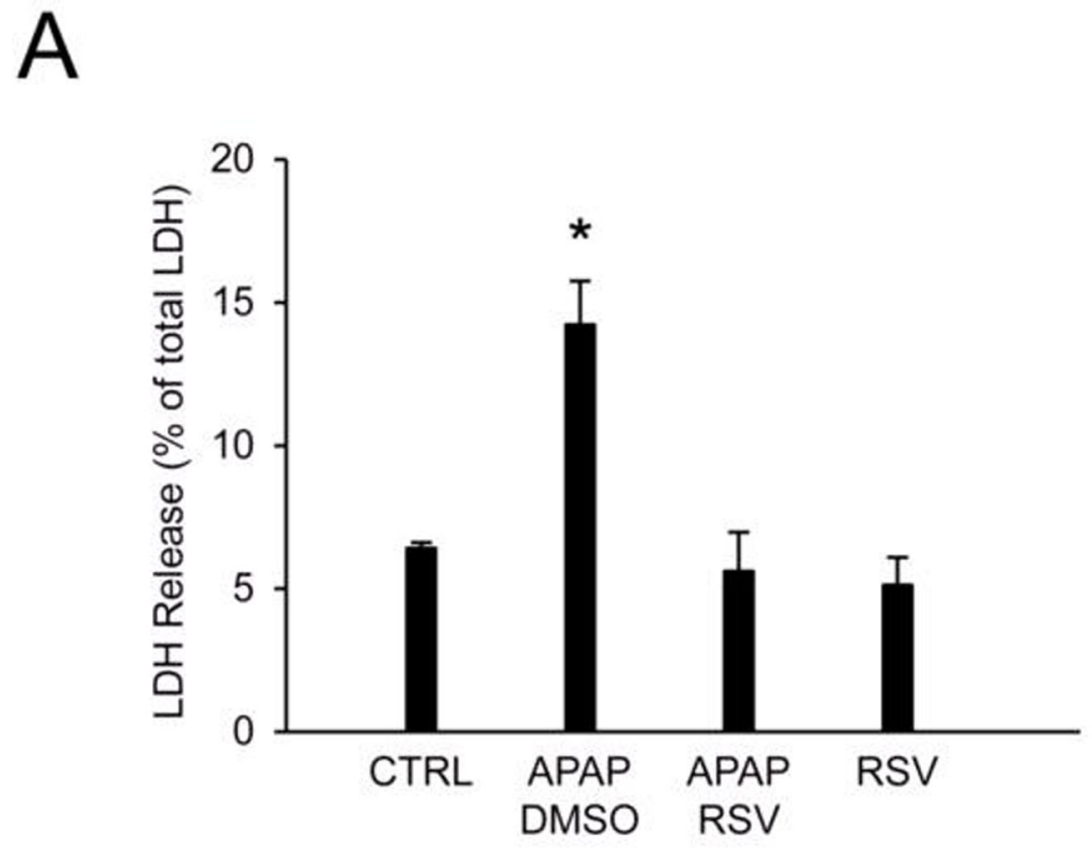

B

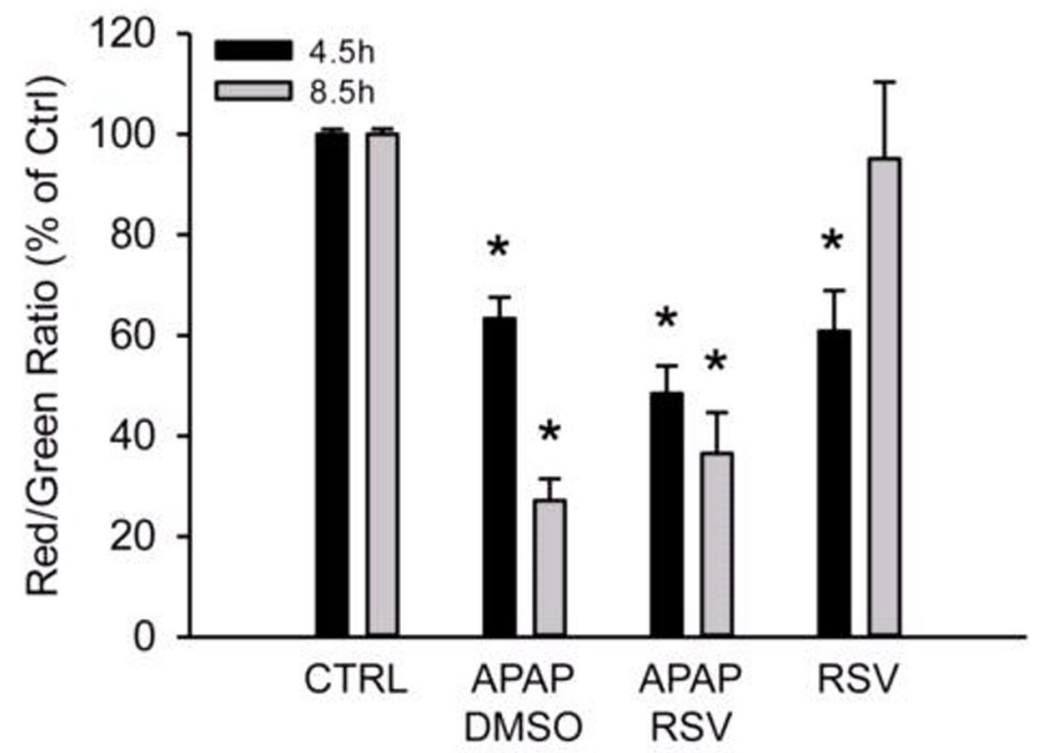

Figure 5. Resveratrol protects against acetaminophen (APAP) toxicity in vitro without preventing loss of mitochondrial membrane potential

Primary mouse hepatocytes were treated with $5 \mathrm{mM}$ APAP and co-treated with either dimethyl sulfoxide (DMSO) vehicle or $100 \mu \mathrm{M}$ resveratrol (RSV). (A) Lactate dehydrogenase $(\mathrm{LDH})$ release into the cell culture medium. (B) Mitochondrial membrane potential, based on JC-1 red/green fluorescence ratio. Bar graphs show mean $\pm \mathrm{SEM}$ for $\mathrm{n}=$ 3 hepatocyte preparations. *P $<0.05$ vs. CTRL. 

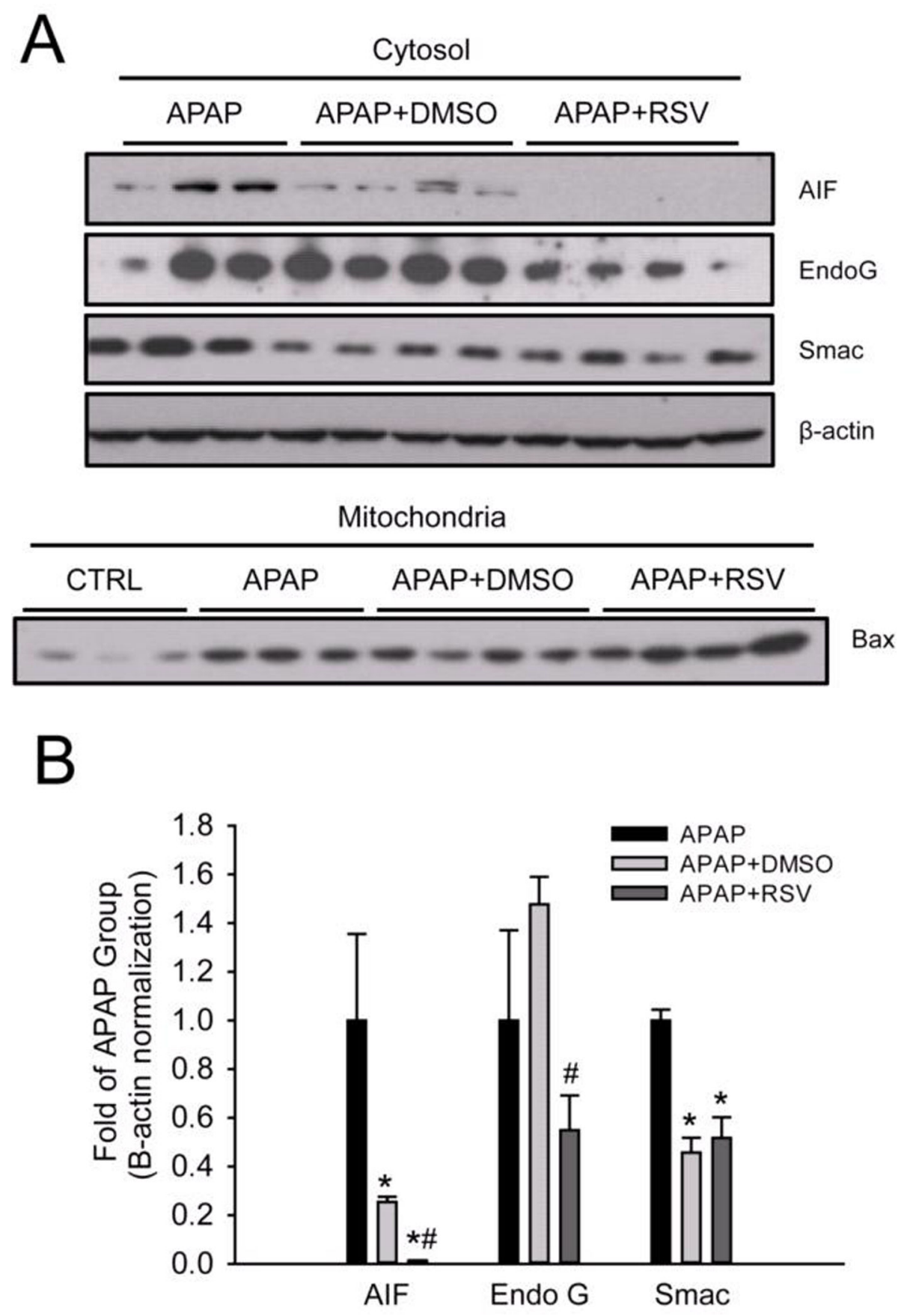

Food Chem Toxicol. Author manuscript; available in PMC 2016 July 01. 

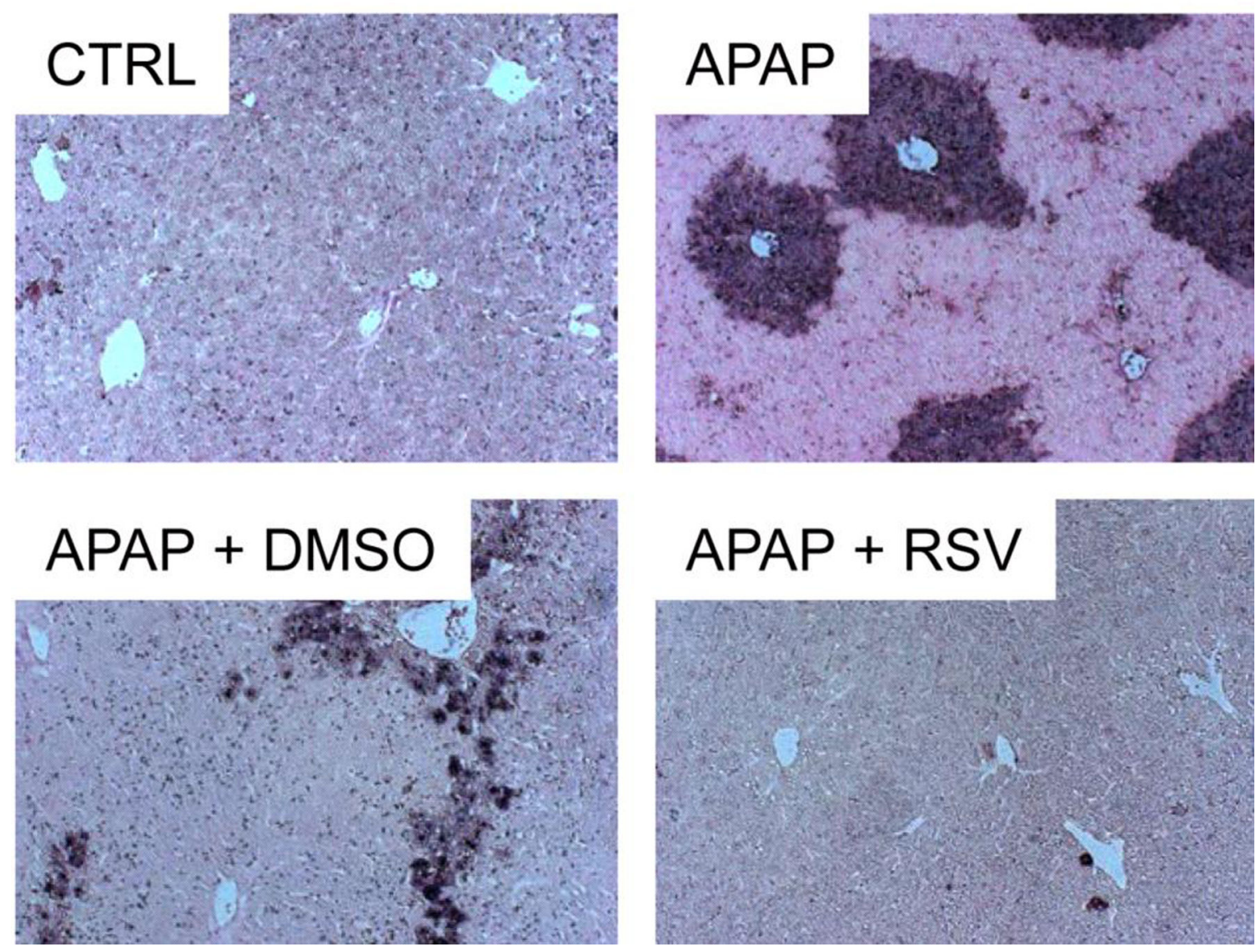

Figure 6. Resveratrol prevents release of endonucleases factor from mitochondria and nuclear DNA fragmentation during acetaminophen (APAP) hepatotoxicity

Mice were treated with $300 \mathrm{mg} / \mathrm{kg}$ APAP followed by dimethyl sulfoxide (DMSO) vehicle or $50 \mathrm{mg} / \mathrm{kg}$ resveratrol (RSV) $1.5 \mathrm{~h}$ later. Liver tissue was harvested at $6 \mathrm{~h}$ post-APAP and mitochondrial and cytosol fractions were isolated. (A) Western blots for apoptosis-induced factor (AIF), endonuclease G (EndoG), and Bax in subcellular fractions. (B) Densitometry. Bar graphs show mean \pm SEM for $n=3-4$ mice. ${ }^{*} \mathrm{P}<0.05$ vs. CTRL. ${ }^{\#} \mathrm{P}<0.05$ vs. APAP + DMSO treatment. (C) Nuclear DNA fragmentation in liver tissue sections as visualized by the TUNEL assay. 


\section{Table 1}

\begin{tabular}{|c|c|c|c|c|c|}
\hline \multirow{6}{*}{ 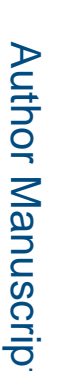 } & \multicolumn{5}{|c|}{ Induction of antioxidant genes } \\
\hline & Gene & CTRL & APAP & APAP + Veh. & APAP + RSV \\
\hline & Gclc & $1.0 \pm 0.16$ & $2.0 \pm 0.36^{*}$ & $4.1 \pm 0.40^{*}$ & $2.7 \pm 0.13^{*}$ \\
\hline & Catalase & $1.0 \pm 0.14$ & $0.63 \pm 0.03$ & $0.58 \pm 0.05$ & $0.56 \pm 0.03^{*}$ \\
\hline & Ho-1 & $1.0 \pm 0.16$ & $63.6 \pm 4.8^{*}$ & $45.2 \pm 3.6^{*}$ & $40.7 \pm 3.1^{*}$ \\
\hline & Sod1 & $1.0 \pm 0.14$ & $1.0 \pm 0.11$ & $1.1 \pm 0.10$ & $1.3 \pm 0.10$ \\
\hline & Sod2 & $1.0 \pm 0.060$ & $0.72 \pm 0.09^{*}$ & $0.73 \pm 0.05^{*}$ & $0.75 \pm 0.04^{*}$ \\
\hline & Mt-1 & $1.0 \pm 0.50$ & $14.3 \pm 1.4^{*}$ & $15.1 \pm 0.71^{*}$ & $19.0 \pm 2.5^{*}$ \\
\hline & Mt-2 & $1.0 \pm 0.69$ & $20.1 \pm 3.2^{*}$ & $15.1 \pm 0.42^{*}$ & $18.1 \pm 0.54^{*}$ \\
\hline
\end{tabular}

Data are expressed as mean \pm SE for $n=3-6$.

p $<0.05$ vs. CTRL. 